\title{
Mapping the Global Digital Divide
}

\author{
D. Steven White* \\ Department of Management and Marketing \\ Charlton College of Business \\ University of Massachusetts-Dartmouth \\ 285 Old Westport Road \\ North Dartmouth, MA 02747 USA \\ swhite@umassd.edu
}

Angappa Gunasekaran

Department of Decision and Information Sciences

Charlton College of Business

University of Massachusetts-Dartmouth

285 Old Westport Road

North Dartmouth, MA 02747 USA

agunasekaran@umassd.edu

Timothy P. Shea

Department of Decision and Information Sciences

Charlton College of Business

University of Massachusetts-Dartmouth

285 Old Westport Road

North Dartmouth, MA 02747 USA

tshea@umassd.edu

Godwin C. Ariguzo

Department of Management and Marketing

Charlton College of Business

University of Massachusetts-Dartmouth

285 Old Westport Road

North Dartmouth, MA 02747 USA

gariguzo@umassd.edu

*Corresponding Author 


\title{
Mapping the Global Digital Divide
}

\begin{abstract}
The global digital divide as a concept is intuitively understood by most academicians, politicians and public policy makers. However, to date little empirical work exists to explain differences in per country access to Information and Communication Technologies (ICTs). The research that does exists places heavy influence on the impact of country wealth, as measured by Gross Domestic Product (GDP) per capita, on the diffusion of ICTs. While GDP per capita certainly influences the diffusion of ICTs within a country, it is not the sole determinant of a country's location versus other countries vis-a-vis the global digital divide.

To investigate and map the global digital divide, as it currently exists, the authors utilize modelbased cluster analysis to determine cohorts of countries based on three variables: personal computers per 100 population, Internet users per 100 population and Internet bandwidth per person. Data for these three variables was obtained from the 2008 International Telecommunications Union (ITU): The World Telecommunication/ Information and Communication Technology (ICT) Indicators Database. Thus, this research is innovative on two levels. First, it introduces model-based cluster analysis to the international business research literature. And second, it introduces the variable of International bandwidth per person as a measure of the global digital divide.

The results indicate that the global digital divide consists of four tiers. And although all of the developed countries are included in the first tier, some surprising results are obtained. Implications of the results are discussed and directions for future research are provided.
\end{abstract}

Keywords: global digital divide, model-based cluster analysis 


\section{Mapping the Global Digital Divide}

\section{Introduction}

Although growth in worldwide Internet penetration was over 600 percent for the seven-year period 1997 through 2004 (Shea et al., 2006), a substantial gap exists globally between those countries with broad access to the Internet and those without. This gap, identified in the literature as the digital divide, has been referred to frequently (and was a catalyst for a new area for discussion, the Bottom of the Pyramid (BoP)) but has never been clearly described. That is, people quickly understand the concept of digital divide but can not accurately describe how specific countries are impacted by this divide. The purpose of this research is to provide a map of the digital divide as it exists currently, using countries as the unit of analysis. By providing a contemporary snapshot of the global digital divide, a baseline for tracking changes and for future investigation is established.

The role of the Internet in the personal and business life of the world today can not be overstated. Since its inception as a global communications system, the Internet has put over one billion people globally in touch with each other (Shea et al., 2006) and has had a profound influence on the global economy (Zhao, 2002). The diffusion of the Internet is theorized to foster a convergence of economic structures (Sharma and Gupta, 2003) and cultures (Lim, 2002) globally. Gutierrez (2004) claims that this interconnectedness may homogenize global society at the expense of local, national and regional cultures. Cultural concerns aside, it is clear that the Internet has had a profoundly positive impact on the growth of the global economy by providing market access to those traditionally limited by geography (Kim and Galliers, 2004). Thus, the diffusion of Internet technology and access to this technology are critical issues for the sustainable economic development of cities, countries and regions. The measurement of the diffusion of the Internet has received attention in the literature as has the concept of the digital divide. Studies focusing on the former seek to identify the variables that assist 
or hinder the diffusion (c.f., Rogers, 2001) and for the latter tend to look at the gap between developed and developing countries (Bagchi, 2005). Deichmann et al. (2007) propose that studying the digital divide is important because of the link between Internet connectivity and the economic and social wellbeing of a population and to facilitate the development of policies to improve the economic and social well-being of that population. Therefore, the focus of this study is a macro-level view (as defined by Kim and Galliers, 2004) of the current status and structure of the global digital divide given the best data available.

\section{Digital Divide Defined}

What is the digital divide? Surprisingly, no one generally accepted definition exists despite concerns expressed by scholars about the perceived gap between rich and poor countries in terms of Internet access (Wallsten, 2005). An evolution of definitions is presented in Table 1 below.

\section{Please Insert Table 1 About Here}

Two common themes appear to be (1) access to Information and Communication Technologies (ICTs) and (2) the use or ability to derive benefit from ICTs. Thus the global digital divide may be summed up as the inequality in access to ICTs and the inequality in the ability to derive benefit from ICTs both between and within countries. And though evidence exits suggesting that access to ICTs is growing faster in developing countries than it is in developed countries (Fink and Kenny, 2003), the gap in access on a country by country basis has not received much attention. Cullen (2001) suggests that those without adequate access to ICTs share some common characteristics including low income, low educational attainment, low literacy and high unemployment.

Chinn and Fairlie (2007) contend that different factors contribute to the global digital divide. Previous studies identify Gross Domestic Product (GDP) per capita as the main predictor of diffusion of ICTs, use of personal computers (PCs) and the Internet (Quibria et al., 2003; Chinn and Fairlie, 
2007; Deichmann et al., 2007). Other influences include the level of political openness (Crenshaw and Robinson, 2007) and social policies (Bagchi, 2005). In the existing literature focusing on the global digital divide, variables investigated include teledensity, Internet access, infrastructure access (Sharma and Gupta, 2003), education and trade (Deichmann et al., 2007). The variables included in this study, as defined below, offer a new perspective on the global digital divide.

\section{Methodology}

To determine the extent of the global digital divide, this analysis utilized a database purchased from International Telecommunications Union (ITU): The World Telecommunication/ Information and Communication Technology (ICT) Indicators Database (11 ${ }^{\text {th }}$ edition, June 2008 update). This database contains time series data for nearly 100 communications statistics. Data for the year 2005 is used as it is the most complete in terms of data collected for the 172 countries included in this analysis.

Three variables indicative of the diffusion of information technology globally are included in the analysis. Two of the ITU variables, personal computers per 100 people (PC100) and Internet users per 100 people (IU100), have been used in previous studies focusing on the digital divide (Bagchi, 2005; Chinn and Fairlie, 2007; Deichmann et al., 2007). PC100 is thought to be highly correlated with GDP per capita and used as a surrogate measure of economic diffusion. IU100 provides a surrogate measure of the degree of the diffusion of technological competence and acceptance within a country. The subtle difference is that IU100 can be higher than PC100 as access is available in educational institutions, libraries and cyber cafes throughout the world.

The third variable, International Internet Bandwidth per Inhabitant (IbitsPP), has not received much attention in previous research regarding the global digital divide although its importance was alluded to by Bagchi (2005) who discussed the need to investigate the quality of Internet access. It is, arguably, the most important measures of the diffusion and use of digital information access because it represents the total capacity of backbone operators within a country to carry Internet traffic (measured 
in bits) divided by the population of the country (Gray, 2008). Thus, it provides a surrogate measure of the degree of interconnectedness of a country in terms of access to the information globally. The authors propose that the higher IbitsPP, the more interconnected the country and the higher the access to the wealth of information available globally via the Internet.

Measures of these three variables (PC100, IU100 and IbitsPP) for 172 countries for the year 2005, the most recent complete data in the database, are the input for a multi-stage cluster analysis designed to provide an accurate contemporary map the global digital divide. Cluster analysis is a wellknown data summary technique (Hair et al., 2006). Historically, one of the limitations of using cluster analysis is determining the optimal number of clusters. Previous researchers have used intuition, decision heuristics or breaks in the plot of eigenvalues to determine the appropriate number of clusters. The technique of model-based cluster analysis overcomes this limitation by mathematically identifying the optimal number of clusters within a given data set (Fraley and Raftery, 2002; 2005; 2006). Modelbased cluster analysis is available in the statistical analysis software package $\mathrm{R}$ ( $\mathrm{R}$ Development Core Team, 2008).

For this project, a multi-stage cluster analysis procedure is employed. The first stage consists of subjecting the data set to a series of model-based cluster analysis to identify the optimal number of clusters per iteration. Once the optimal number of clusters per level is identified, a k-means cluster analysis using the Hartigan and Wong (1979) algorithm is used to determine group centers (means) and to identify cluster membership. The combination of the two techniques allows for the development of a multitiered map depicting the status of the global digital divide given the most recent complete data available.

\section{Results}

The results are presented in Table 2 and serve to both define the global digital divide and debunk some of the assumptions regarding the global digital divide. 
Please Insert Table 2 About Here

As illustrated in Table 2, the need for utilizing a multi-stage cluster analysis is evident at each level of analysis. The initial combination of model-based cluster analysis and k-means cluster analysis divides the 172 countries in the database into six distinct clusters: Cluster 1 (Denmark), Cluster 2 (five countries), Cluster 3 (12 countries), Cluster 4 (nine countries), Cluster 5 (14 countries) and one final cluster consisting of 131 countries.

A second iteration of model-based cluster analysis and k-means cluster analysis is performed on the cluster containing 131 countries to explore differences within the large number of countries represented and to define membership in the next tier. This procedure was replicated two more times to produce four tiers or levels of about equal size: Tier $1=41$ countries, Tier $2=41$ countries, Tier $3=37$ countries and Tier $4=53$ countries. And while it may have been possible to continue the iterative process (the final cluster contains 53 countries), the relative lack of variance within the final cluster suggests that little additional insight would be gained by doing so.

With few exceptions, the average number of Internet users per 100 population within each cluster is greater than the average number of personal computers per 100 population (exceptions are cluster one, three and eleven). And the importance of variable three (IbitsPP) in contributing to the results is evident by analyzing the difference in that variable between clusters. The cluster map, as presented in Figure 1, presents the four tiers of the global digital divide with each tier arranged from top to bottom in terms of variable three. Overall, the variable IbitsPP has the greatest weight in determining cluster membership. On average, as a country increases its IbitsPP by a factor of 2.265 times, it advances one cluster position. 
Please Insert Figure 1 About Here

The results suggest that while the global digital divide does, in fact, exist, some of the original assumptions regarding the global digital divide are not accurate. For instance, previous research has characterized the global digital divide as one between developed and developing nations (e.g., Castells, 2001) or between rich and poor nations (e.g., Gutierrez, 2004; Wallsten, 2005; James, 2007). The presence of Jamaica, Antiqua, Estonia, Hungary, Slovak Republic, Aruba, Barbados, Brunei, Chile, Latvia, Lithuania, Qatar, Slovenia and the United Arab Emirates in the top tier of the digital divide provides evidence that refutes the assumption that GDP per capita is the main predictor of global Internet access. Likewise, who could predict that both Columbia and Uruguay would be in the top of the second tier of the global digital divide, while three of the four BRIC countries (Brazil, Russia and China) would be in the bottom cluster of the second tier? Another assumption inherent in the previous definitions of the digital divide is that it consists of two tiers (haves versus have nots; rich versus poor). The results of this study support the presence of at least four tiers, and possibly more, depending on the variables investigated.

Even within Tier 1, some surprising observations include the presence of the USA in cluster four, indicating that at least 18 countries outperform it in terms of Internet access and bandwidth per person. And while Tier 1 does contain a prevalence of developed countries, there are notable exceptions as highlighted above. Unfortunately, evidence exists that perpetuates some of the assumptions regarding the global digital divide. African countries account for a majority of the members of the final cluster, indicating a disadvantage for the continent in terms of the personal computers per 100 people, Internet users per 100 people and international Internet bandwidth per person. The mean values of each variable for Cluster $14(1.10,1.25$ and 1.39) are significantly less than 
that of Cluster $1(69.46,52.55$ and 34,702.49) and represent the amount of work to be done to bring the equal access to the global digital environment to the continent.

\section{Implications of the Global Digital Divide}

As the results of the model-based cluster analysis suggest, and as reported by Cullen (2001), there is no easy solution to the problem of the global digital divide. How does one address the gap between Cluster 1 and Cluster 14 when the difference in average access is so pronounced (63 times more access per capita to PCs, 42 times more users per capita of the Internet and 24,965.8 times more Internet bandwidth per capita)? Crenshaw and Robinson (2007) contend that gaps in access this large hinder the transformative power of the Internet for the world's poorest nations. Okoli and Mbarika (2003) extend this argument further by claiming that, on average, developed countries are reaping enormous benefits from ICTs while developing countries are not. Although this article highlights the inclusion of some developing countries in the Tier 1 of the global digital divide, it also provides evidence for the arguments presented above: that there exists a large percent of the global population without access to major forms of information technology (James, 2007). Shea et al. (2006) estimate that only 20 percent or so of the global population is benefiting from access to and use of the Internet.

Likewise, it is clear that the policies national governments play an important role in the diffusion of and access to ICTs within a countries borders. Countries who make ICT infrastructure development and access a priority reap the benefits associated with increased access (Mutula, 2005, 2005b). However access alone, although necessary, is not sufficient. Fryer and Granger (2008) contend that to adequate address the global digital divide, the emphasis has to change from access alone to using digital technology for empowerment. Access to ICTs provides rural populations with access to information that enhances their ability to access and provide education, conduct commerce and to interact with the world at large. The old adage remains as true today as was centuries ago: knowledge is power. Unfortunately, the hindrance of knowledge and limits to its access also represents power. 
Thus, governments who seek to repress free speech and access to information are less likely to invest in adequate levels of infrastructure to support the diffusion of ICTs within the country, thus perpetuating the negative impacts associated with the global digital divide.

Not all of the news regarding the global digital divide is negative. Fink and Kenny (2003) contend that evidence suggests that the per capita global digital divide is shrinking. Likewise, Sarrocco (2002), advocates broadening access in developed countries from the urban areas (where it is currently) to the rural areas. Fryer and Granger (2008) stress that all populations, regardless of location, benefit from closing the gap in the global digital divide.

\section{Summary and Conclusion}

Purcell and Toland (2004) indicate that a major challenge of the new millennium is to make certain that all world citizens benefit from open access to ICTs. This contention is supported by Wood (2004) defines the greatest benefit that access to ICTs provides developing countries is opportunity. Access to ICTs in developing nations fosters economic opportunities for all (Lim, 2002; Kim and Galliers, 2004; Wood, 2004). Internet access has the potential to foster economic development in sectors as diverse as tourism, agriculture and handicrafts (Rao, 2001).

By providing a contemporary map of the global digital divide, this research provides a baseline measure of the investment in ICTs needed on a per country basis in order to close the gap as it currently exists. Paul (2002) cautions that gaps in ICTs are not static nor are the impacts of new technologies equal: with the introduction of each new ICT technology, the global digital divide has the potential to widen. Thus, the importance of measuring the diffusion of ICT technologies remains. Fortunately, research exists (c.f., Brown et al., 2004; Wolcott et al., 2001) the provides a template known as the Global Diffusion of the Internet (GDI) framework consisting of six dimensions: pervasiveness (number of Internet users per capita), sophistication of use, geographic dispersion, sectoral absorption 
(commerce, education, health and public service), connectivity infrastructure and organizational infrastructure.

Investment by developed countries into the ICT infrastructure of developing countries makes sense on too many levels to ignore. Providing access to ICTs increases opportunities for all involved, especially in terms of sustainable economic development and market access. 


\section{References}

Bagchi, Kallol (2005), "Factors Contributing to Global Digital Divide: Some Empirical Results", Journal of Global Information Technology Management, Vol. 8, No. 3, pp. 47-65.

Brown, Irwin, Rudi Hoppe, Pauline Mugera, Paul Newman and Adrie Stander (2004), “The Impact of National Environment on the Adoption of Internet Banking: Comparing Singapore and South Africa", Journal of Global Information Management, Vol. 12, No. 2, pp. 1-26.

Castells, Manuel (2001), The Internet Galaxy: Reflections on the Internet, Business and Society. Oxford: University Press.

Chinn, Menzie D. and Robert W. Fairlie (2007), "The Determinants of the Global Digital Divide: A Cross-Country Analysis of Computer and Internet Penetration", Oxford Economic Papers, Vol. 59, No. 1, pp. 16-44.

Colby, Dean (2001), "Conceptualizing the "Digital Divide": Closing the "Gap" by Creating a Postmodern Network that Distributes the Productive Power of Speech", Communication Law \& Policy, Vol. 6, No. 1, pp. 123-173.

Crenshaw, Edward M. and Kristopher K. Robison (2006), "Jump-Starting the Internet Revolution: How Structural Conduciveness and Global Connections Help Diffuse the Internet", Journal of the Association for Information Systems, Vol. 7, No. 1, pp. 4-18.

Cullen, Rowena (2001), “Addressing the Digital Divide”, Online Information Review, Vol. 25, No. 5, pp. 311-320.

Dasgupta, Susmita, Somik Lall and David Wheeler (2001), "Policy Reform, Economic Growth, and the Digital Divide: An Economic Analysis", World Bank Policy Research Paper no. 2567, World Bank, Washington, DC.

Deichmann, Joel I., Abdolreza Eshghi, Dominique Haughton, Michele Masnghetti, Selin Sayek and Heikki Topi (2006), "Exploring Break-Points and Interaction Effects Among Predictors of the International Digital Divide” Journal of Global Information Technology Management, Vol. 9, No. 4, pp. 47-71.

Fink, Carsten and Charles J. Kenny (2003), “W(h)ither the Digital Divide?”, Info, Vol. 5, No. 6, pp. $15-24$.

Fraley, Chris and Adrian.E. Raftery (2002), "Model-based Clustering, Discriminant Analysis and Density Estimation", Journal of the American Statistical Association, Vol. 97, No. 458, pp. 611-631.

Fraley, Chris and Adrian.E. Raftery (2005), "Bayesian Regularization for Normal Mixture Estimation and Model-Based Clustering”, Technical Report, Department of Statistics, University of Washington. 
Fraley, Chris and Adrian.E. Raftery (2006), "MCLUST Version 3 for R: Normal Mixture Model-Based Clustering", Technical Report No. 504, Department of Statistics, University of Washington, September 2006.

Fryer, Deidra and Mary J. Granger (2008), "Closing the Digital Divide: The Role of Community Based Non-Profit Organizations”, Journal of Global Information Technology Management, Vol. 11, No. 1, pp. 1-5.

Genus, Audley and Mohd Ali Mohamad Nor (2005), "Closing the Digital Divide: The Role of Community Based Non-Profit Organizations", Journal of Electronic Commerce in Organizations, Vol. 3, No. 2, pp. 82-94.

Gray, Vanessa (2008), "Revision of Core Indicators A1-A12: Infrastructure and Access”, 2008 Global Event on Measuring the Information Society: Partnership on Measuring ICT for Development, Session 3, International Telecommunications Union (ITU) Infrastructure, Geneva, Switzerland, 27 May 2008.

Gutierrez, Miguel Angel (2004), "Latin America and the Digital Economy Challenge", Foresight, Vol. 6, No. 3, pp. 163-172.

Hair, Joseph F. Jr., William C. Black, Barry J. Babin, Rolph E. Anderson, Ronald L. Tatham (2006), “Cluster Analysis", Chapter 8, Multivariate Data Analysis, ${ }^{\text {th }}$ Edition, Upper Saddle River, NJ: Pearson/Prentice Hall, pp. 555-628.

Hartigan, John A. and M. Anthony Wong (1979), “A K-Means Clustering Algorithm”, Applied Statistics, Vol. 28, No. 1, pp. 100-108.

International Telecommunications Union (2008), The World Telecommunication/ Information and Communication Technology (ICT) Indicators Database, $11^{\text {th }}$ edition, June 2008 update. http://www.itu.int/net/home/index.aspx

James, Jeffrey (2007), "From Origins to Implications: Key Aspects in the Debate Over the Digital Divide", Journal of Information Technology, Vol. 22, No. 1, pp. 284-295.

Kim, Changsu and Robert D. Galliers (2004), "Toward a Diffusion Model for Internet Systems", Internet Research, Vol. 14, No. 2, pp. 155-166.

Lim, Jamus Jerome (2002), "East Asia in the Information Economy: Opportunities and Challenges", Info, Vol. 4, No. 5, pp. 56-63.

Mutula, Stephen M. (2005), "Peculiarities of the Digital Divide in sub-Saharan Africa", Program: Electronic Library and Information Systems, Vol. 39, No. 2, pp. 122-138.

Mutula, Stephen M. (2005b), "Bridging the Digital Divide Through E-Governance: A Proposal for Africa's Libraries and Information Centers", The Electronic Library, Vol. 23, No. 5, pp. 591602. 
Okoli, Chitu and Victor A.W. Mbarika (2003), “A Framework for Assessing E-Commerce in SubSaharan Africa”, Journal of Global Information Technology Management, Vol. 6, No. 3, pp. 44-66.

Paul, Johnson (2002), "Narrowing the Digital Divide: Initiatives Undertaken by the Association of South-East Asian Nations (ASEAN)", Program: Electronic Library and Information Systems, Vol. 36, No. 1, pp. 13-22.

Purcell, Fuatai and Janet Toland (2004), "Electronic Commerce for the South Pacific: A Review of EReadiness", Electronic Commerce Research, Vol. 4, No. 3, pp. 241-262.

Quibria, M.G., Shamsun A. Ahmed, Ted Tschang and Mari-Len Reyes-Macasaquit (2003), "Digital Divide: Determinants and Policies with Special Reference to Asia", Journal of Asian Economics, Vol. 13, No. 6, pp. 811-825.

R Development Core Team (2008). R: A Language and Environment for Statistical Computing. R Foundation for Statistical Computing, Vienna, Austria. ISBN 3-900051-07-0, URL http://www.R-project.org.

Rao, Madanmohan (2001), "Internet Fever Reaches the Top of the World", Appropriate Technology, Vol. 28, No. 2, pp. 31-32.

Rogers, Everett M. (2001), “The Digital Divide”, Convergence: The International Journal of Research into New Media Technologies, Vol. 7, No. 4, pp. 96-111.

Sarrocco, Claudia (2002), "Improving IP Connectivity in the Least Developed Countries: Breaking the Vicious Circle", Info, Vol. 4, No. 3, pp. 14-28.

Sharma, Sushil K. and Jatiner N.D. Gupta (2003), "Socio-Economic Influences of E-Commerce Adoption”, Journal of Global Information Technology Management, Vol. 6, No. 3, pp. 3-21.

Shea, Timothy, Godwin Ariguzo and D. Steven White (2006), "Putting the World in the World Wide Web: The Globalization of the Internet", International Journal of Business Information Systems, Vol. 2, No. 1, pp. 75-98.

Wallsten, Scott (2005), "Regulation and Internet Use in Developing Countries", Economic Development and Cultural Change, Vol. 53, No. 2, pp. 501-523.

Wolcott, Peter, Larry Press, William McHenry, Seymour Goodman and William Foster (2001), “A Frame-Work for Assessing the Global Diffusion of the Internet", Journal of the Association for Information Systems, Vol. 2, No. 6, pp. 1-50.

Wood, Charles M. (2004), "Marketing and E-Commerce as Tools of Development in the Asia-Pacific Region: A Dual Path”, International Marketing Review, Vol. 21, No. 3, pp. 301-320. 
Zhao, HongXin (2002), "Rapid Internet Development in China: A Discussion of Opportunities and Constraints on Future Growth", Thunderbird International Business Review, Vol. 44, No. 1, pp. 119-138. 


\section{Author Biographies}

D. Steven White, D.B.A., is the chairperson of the Department of Management \& Marketing and Professor of Marketing \& International Business. He received his doctorate in Marketing with a minor in Information Systems from Cleveland State University. His research has been published in International Marketing Review, Journal of Business Research, Journal of Services Marketing, Thunderbird International Business Review, Journal of Marketing Management (U.K.), Journal of Marketing Education and International Business Review. He teaches undergraduate and graduate classes in Marketing Research, International Marketing and International Business.

Angappa Gunasekaran, Ph.D., is a Professor of Operations Management and the Chairperson of the Department of Decision and Information Science at the Charlton College of Business, the University of Massachusetts-Dartmouth, USA. He has over 200 articles published in 40 different peer-reviewed journals. He has presented over 50 papers and published about 50 articles in conferences and given a number of invited talks in about 20 countries. He is on the Editorial Board of over 20 journals. He has several edited books. He is the Editor of several journals in the fields of operations management and information systems. He is currently interested in researching benchmarking, management information systems, e-commerce (B2B), information technology/systems evaluation, performance measures and metrics in new economies, technology management, logistics and supply chain management. $\mathrm{He}$ is the Director of the Business Innovation Research Center at the University of Massachusetts-Dartmouth and received grants over $\$ 300,000$ to support his research and other academic activities.

Timothy Shea, D.B.A., is an Associate Professor of Management Information Systems. Dr. Shea first worked in industry and management consulting developing large systems applications and early CASE tools. He received his doctorate in Management Information Systems from Boston University. Dr. Shea's research has focused on the delivery and management of web-based learning and teaching technologies, corporate universities, end-user training, implementation issues around ERP's, ecommerce, and communities of practice. He has 18 journal articles published, 7 book chapters, 4 training manuals, and over 50 conference presentations. He teaches undergraduate and graduate MIS classes including Advanced Projects, Database, Networking, and E-Business.

Dr. Godwin Ariguzo, Ed.D., is a Lecturer in the Marketing and Management Department in the Charlton College of Business at the University of Massachusetts Dartmouth. He also serves as a visiting professor at Fachhochshule Braunschweig/Wolfenbuttel (University of Applied Sciences) in Wolfsburg, Germany. He has publications in the Information and Management Journal, the International Journal of Logistics Systems and Management, International Journal of Business Innovation and Research, and in numerous conference proceedings. He was the recipient of the 2005 University of Massachusetts Dartmouth Leo M. Sullivan Teacher of the Year and Charlton College of Business Higginson Award for Excellence in Teaching in 2005. He served as a content consultant to WGBH Educational Television Foundation in Boston and was a recipient of a $\$ 250,000$ grant from Microsoft@ to develop and implement computer training programs. 
Table 1: Digital Divide Defined Chronologically

\begin{tabular}{|c|c|}
\hline Definition & Citation \\
\hline Digital divide is characterized as a lack of telecommunications access. & $\begin{array}{l}\text { Dasgupta, Lall and } \\
\text { Wheeler, } 2001\end{array}$ \\
\hline $\begin{array}{l}\text { Digital divide is a large divide between developed and developing nations and the } \\
\text { challenges it presents in terms of ownership and control of data, and exclusion of groups } \\
\text { by virtue of education, technology and national cultures. }\end{array}$ & Castells, 2001 \\
\hline $\begin{array}{l}\text {..the disparity in access across classifications of race, gender, age, income, and } \\
\text { education to telephone, personal computers, and the Internet. }\end{array}$ & Colby, 2001 \\
\hline $\begin{array}{l}\text { The digital divide is defined as the gap that exists between individuals advantaged by the } \\
\text { Internet and those individuals relatively disadvantaged by the Internet. }\end{array}$ & Rogers, 2001 \\
\hline $\begin{array}{l}\text { The term digital divide refers to the unequal and disproportionate pace of development in } \\
\text { societies in having access to digital infrastructure and services. }\end{array}$ & Paul, 2002 \\
\hline $\begin{array}{l}\text { The digital divide is the gap between individuals, households, businesses and geographic } \\
\text { areas at different socio-economic levels with regard to their opportunities to access } \\
\text { Information and Communication Technologies (ICTs) and the Internet. }\end{array}$ & Lim, 2002 \\
\hline $\begin{array}{l}\text { Digital divide }-4 \text { interpretations: } \\
\text { 1) a gap in access to use of ICTs, } \\
\text { 2) a gap in the ability to use ICTs, } \\
\text { 3) a gap in actual use, } \\
\text { 4) a gap in the impact of use }\end{array}$ & Fink and Kenny, 2003 \\
\hline $\begin{array}{l}\text { The gap between rich and poor is represented in the digital world between the people } \\
\text { who have access to information and those who do not. }\end{array}$ & Gutierrez, 2004 \\
\hline $\begin{array}{l}\text { The digital divide may be defined as inequitable access to ICTs by individuals or groups } \\
\text { of people in a country or between countries. }\end{array}$ & Mutula, 2005 \\
\hline $\begin{array}{l}\text { Digital divide is defined as the division between those who have real access to ICT and } \\
\text { are using it effectively and those who don't. }\end{array}$ & Bagchi, 2005 \\
\hline $\begin{array}{l}\text { The digital divide is a phenomenon associated with disparities between groups and } \\
\text { societies in the adoption and diffusion of electronic ICTs and e-business practices. }\end{array}$ & Genus and Noor, 2005 \\
\hline $\begin{array}{l}\text { The International Telecommunications Union (ITU) defines the digital divide as the } \\
\text { inequalities in access to and utilization of ICTs }\end{array}$ & Mutula, 2005b \\
\hline $\begin{array}{l}\text { (The digital divide is) ....the differential extent to which rich and poor countries benefit } \\
\text { from various forms of information technology. }\end{array}$ & James, 2007 \\
\hline $\begin{array}{l}\text { The digital divide characterizes the gap that exists between those populations who are } \\
\text { able to benefit from digital technologies and those who are not. }\end{array}$ & $\begin{array}{l}\text { Fryer and Granger, } \\
2008\end{array}$ \\
\hline
\end{tabular}


TABLE 2: Cluster Means for 172 Countries

TIER 1

\begin{tabular}{|c|l|c|r|r|}
\hline Cluster & \multicolumn{1}{|c|}{ Countries } & \multicolumn{1}{c|}{ PC100 } & \multicolumn{1}{c|}{ IU100 } & IbitsPP \\
\hline $\mathbf{1}$ & Denmark & 69.458382 & 52.554142 & 34702.492 \\
\hline $\mathbf{2}$ & Jamaica, Luxembourg, Netherlands, Sweden, UK & 62.926851 & 65.495098 & 17437.902 \\
\hline $\mathbf{3}$ & $\begin{array}{l}\text { Antigua, Austria, Belgium, Bermuda, Canada, } \\
\text { Germany, HK, Ireland, Norway, San Marino, } \\
\text { Singapore, Switzerland }\end{array}$ & 58.322394 & 51.141985 & 7576.5386 \\
\hline $\mathbf{4}$ & $\begin{array}{l}\text { Estonia, Finland, France, Hungary, Iceland, Slovak } \\
\text { Republic, Spain, Taiwan, USA }\end{array}$ & 46.508244 & 48.936175 & 3605.8125 \\
\hline $\mathbf{5}$ & $\begin{array}{l}\text { Aruba, Barbados, Brunei, Chile, Italy, Japan, South } \\
\text { Korea, Latvia, Lithuania, New Zealand, Portugal, } \\
\text { Qatar, Slovenia, United Arab Emirates }\end{array}$ & 26.249112 & 43.623137 & 1322.0470 \\
\hline & 131 other countries & 5.650156 & 8.707035 & 97.38774 \\
\hline
\end{tabular}

TIER 2

\begin{tabular}{|c|l|r|r|r|}
\hline Cluster & \multicolumn{1}{|c|}{ Countries } & \multicolumn{1}{|c|}{ PC100 } & \multicolumn{1}{|c|}{ IU100 } & IbitsPP \\
\hline $\mathbf{6}$ & $\begin{array}{l}\text { Bahrain, Belize, Columbia, Cyprus, Greece, New } \\
\text { Caledonia, Poland, Puerto Rico, Romania, Uruguay }\end{array}$ & 13.792581 & 22.88312 & 540.94552 \\
\hline $\mathbf{7}$ & $\begin{array}{l}\text { Argentina, French Polynesia, Kuwait, Peru, Trinidad \& } \\
\text { Tobago, Turkey }\end{array}$ & 11.296220 & 18.25523 & 354.74290 \\
\hline $\mathbf{8}$ & $\begin{array}{l}\text { Bahamas, Costa Rica, Maldives, Morocco, Oman, Panama, } \\
\text { Seychelles, Tuvalu }\end{array}$ & 11.285229 & 17.00382 & 237.10425 \\
\hline $\mathbf{9}$ & $\begin{array}{l}\text { Brazil, China, Djibouti, Ecuador, Egypt, Fiji, Gabon, } \\
\text { Lebanon, Malaysia, Mauritius, Mexico, Moldova, Russia, } \\
\text { Senegal, Suriname, Thailand, Tunisia }\end{array}$ & 8.380002 & 12.81880 & 98.48574 \\
\hline & 90 other countries & 3.355191 & 4.73465 & 14.92549 \\
\hline
\end{tabular}

TIER 3

\begin{tabular}{|c|l|c|c|c|}
\hline Cluster & \multicolumn{1}{|c|}{ Countries } & PC100 & IU100 & IbitsPP \\
\hline $\mathbf{1 0}$ & $\begin{array}{l}\text { Azerbaijan, Belarus, Bolivia, Bosnia \& Herzegovina, } \\
\text { Guatemala, Guyana, Jordan, Kyrgyzstan, Micronesia, } \\
\text { Paraguay, Philippines, Samoa, Saudi Arabia, Venezuela, } \\
\text { Vietnam }\end{array}$ & 4.946000 & 12.214000 & 47.788000 \\
\hline $\mathbf{1 1}$ & $\begin{array}{l}\text { Armenia, Botswana, Cape Verde, El Salvador, Equatorial } \\
\text { Guinea, Haiti, India, Libya, Macedonia, Mauritania, } \\
\text { Mongolia, Namibia, Sao Tome \& Principe, Solomon } \\
\text { Islands, South Africa, Sri Lanka, St. Vincent \& the } \\
\text { Grenadines, Syria, Tonga, Turkmenistan, Ukraine, Vanuatu }\end{array}$ & 6.536364 & 5.764545 & 21.177273 \\
\hline & 53 other countries & 1.584906 & 2.190566 & 3.030566 \\
\hline
\end{tabular}

TIER 4

\begin{tabular}{|c|l|c|r|r|}
\hline Cluster & \multicolumn{1}{|c|}{ Countries } & PC100 & \multicolumn{1}{|c|}{ IU100 } & IbitsPP \\
\hline $\mathbf{1 2}$ & $\begin{array}{l}\text { Benin, Bhutan, Burkina Faso, Cameroon, Cuba, Gambia, } \\
\text { Ghana, Honduras, Indonesia, Rwanda, Sudan, Uzbekistan }\end{array}$ & 2.072500 & 2.180833 & 6.904167 \\
\hline $\mathbf{1 3}$ & $\begin{array}{l}\text { Albania, Algeria, Dominican Republic, Georgia, Togo, } \\
\text { Zimbabwe }\end{array}$ & 3.430000 & 7.673333 & 4.828333 \\
\hline $\mathbf{1 4}$ & $\begin{array}{l}\text { Afghanistan, Angola, Bangladesh, Burundi, Cambodia, } \\
\text { Central African Republic, Chad, Comoros, Congo, } \\
\text { Democratic Republic of the Congo, Cote d'Ivoire, Eritrea, } \\
\text { Ethiopia, Guinea, Guinea-Bissau, Kenya, Laos, Lesotho, } \\
\text { Madagascar, Malawi, Mali, Mozambique, Myanmar, } \\
\text { Nepal, Nicaragua, Niger, Nigeria, Papua New Guinea, } \\
\text { Somalia, Swaziland, Tajikistan, Tanzania, Uganda, Yemen, } \\
\text { Zambia }\end{array}$ & 1.101429 & 1.254000 & 1.394286 \\
& & & & \\
\hline
\end{tabular}


FIGURE 1: Map of the Global Digital Divide ( $n=172$ countries)

\section{TIER 1}

\section{Denmark}

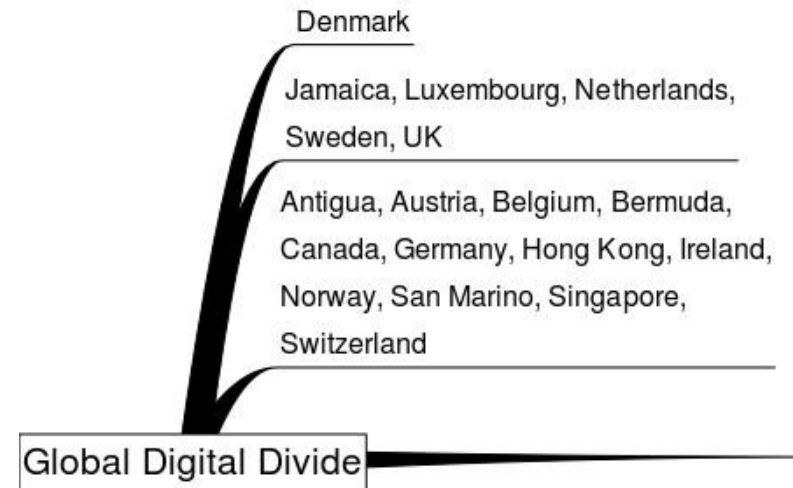

Global Digital Divide

Estonia, Finland, France, Hungary,

Iceland, Slovak Republic, Spain, Taiwan,

USA

Aruba, Barbados, Brunei, Chile, Italy,

Japan, South Korea, Latvia, Lithuania,

New Zealand, Portugal, Qatar, Slovenia,

United Arab Emirates

\section{TIER 2}

Bahrain, Belize, Columbia, Cyprus,

Greece, New Caledonia, Poland, Puerto

Rico, Romania, Uruguay

Argentina, French Polynesia, Kuwait,

Peru, Trinidad \& Tobago, Turkey

Bahamas, Costa Rica, Maldives, Morocco,

Oman, Panama, Seychelles, Tuvalu

Brazil, China, Djibouti, Equador, Egypt,

Fiji, Gabon, Lebanon, Malaysia,

Mauritius, Mexico, Moldova, Russia,

Senegal, Suriname, Thailand, Tunisia

\section{TIER 3}

TIER 4

Azerbaijan, Belarus, Bolivia, Bosnia \& Herzegovinia, Guatemala, Guyana, Jordan,

Kyrgyzstan, Micronesia, Paraguay,

Philippines, Samoa, Saudi Arabia,

Venezuela, Vietnam

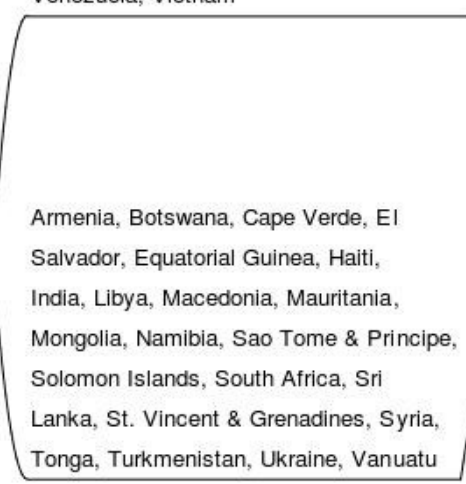

Benin, Bhutan, Burkina Faso, Cameroon, Cuba, Gambia, Ghana, Honduras,

Indonesia, Rwanda, Sudan, Uzbekistan Albania, Algeria, Dominican Republic, Georgia, Togo, Zimbabwe Afghanistan, Angola, Bangladesh, Burundi, Cambodia, Central African Republic, Chad, Comoros, Congo, Democratic Republic of Congo, Cote d'lvoire, Eritrea, Ethiopia, Guinea, Guinea-Bissau, Kenya, Laos, Lesotho, Madagascar, Malawi, Mali, Mozambique, Myanmar, Nepal, Nicaragua, Niger,

Nigeria, Papua New Guinea, Somalia, Swaziland, Tajikistan, Tanzania, Uganda, Yemen, Zambia 